\title{
French increase ties with industry but researchers still face hurdles
}

Paris. France's largest research organization, the FF11-billion (US $\$ 2.2$ billion) a year Centre National de la Recherche Scientifique (CNRS), is working more with industry than ever. Although its collaborations have had a significant and growing impact, according to a study completed last month, problems remain: too many of the contracts are brief flirtations that fail to develop into serious relationships, the average value of contracts is tiny and scientists often fail to communicate properly with their industrial partners. In addition, the CNRS is losing money on its hoard of patents.

"All we have shown is that we can work with industry", says Pierre Vergnon, head of industrial relations at the CNRS. "We have unblocked the situation, but we are far from where we want to go."

There is no question that more scientists are spending time with their industrial counterparts. This year, 625 CNRS laboratories hold contracts worth FF550 million with 900 companies; in 1983, the figures were 150 laboratories, FF39 million in contracts and 120 companies. The numbers reflect a significant change in attitude for an organization that once actively discouraged such collaboration. The change occurred in 1982, when the government told the CNRS to start justifying its budget with more than research papers and to 'go forth and multiply' its contacts with industry.

For some scientists, industrial contacts are simply a matter of keeping the wolf from the door. Because three-quarters of the CNRS budget is spent on salaries, there is never enough money for the increasingly expensive equipment and supplies that researchers need. Collaboration can also mean higher pay, as well as more postgraduate students. Although companies are technically not permitted to pay researchers, CNRS discreetly allows them to serve as consultants for one day a week. Consultants can earn as much as they like during that time; of the 515 scientists who applied for this status in 1990, none was denied permission.

However, even if more scientists are willing to work with industry, few are knocking on company doors with their laboratory books open; in more than 80 per cent of collaborations, companies took the initiative. And although the historic barriers between the two groups have been lowered, they remain formidable.

A study by a Paris company, Central Management, estimates that collaboration was worth FF1 billion annually to the French economy in 1991 through new products, processes or improved technologies. Although that figure excludes such intangibles as the ideas that flow from a collaboration or the additional talent that is put to work on a project, it also hides the fact that a few products - for example, a new lightweight polymer used in apparel and medicine and a new fuel for the Ariane space rocket - account for most of the total.

A survey of more than 90 CNRS researchers and industry officials found that "frustration and deception" are common complaints of scientists who collaborate with industry. Researchers feel that they are

\section{Swiss launch environment programme}

Basel. Swiss environmental scientists are celebrating the government's decision to spend SFr34 million (US\$26 million) over the next three years in grants covering environmental technology and research. The new programme is the biggest environmental research initiative in the country's history.

The Swiss parliament had approved SFr57 million for the programme, to be administered by the Swiss National Science Foundation, but the finance ministry trimmed that amount as part of an overall effort to curb spending. The initiative sets aside SFr5 million for research on biodiversity, reflecting an increased interest in the environment by the Swiss government in response to the Earth Summit in Rio de Janeiro earlier this year and pressure from Swiss scientists.

The programme will concentrate on basic research, which sets it apart from those elsewhere in Europe. The European Communities are spending ECU414 million (US\$570 million) on technological approaches to environmental protection and to climate research, as are national programmes in France and Germany. The Swiss have postponed supporting research on biogeochemical processes and issues affecting the developing world until 1996, when parliament says it will add money to the programme.

Nevertheless, the initiative represents a significant portion of the SFr280 million that the Swiss government now spends annually on research. Some 700 applications have already been received and are being reviewed but fewer than 10 per cent of them are expected to be funded.

Oliver Klaffke forgotten once their results are turned in, while companies complain that the CNRS moves too slowly in approving proposed collaborations. The study concludes that the CNRS could avoid such problems if it took greater care in matching its scientists with the right companies.

Some 30 laboratories have set up joint operations with industry, including a successful collaboration with the pharmaceutical company Roussel Uclaf. Vergnon of CNRS would like more laboratories to develop such ties with industry, although an author of the recent report, François Finkbeiner, warns that "CNRS must be vigilant not to become a subcontractor" to industry. Indeed, Vergnon says that half-adozen small laboratories once associated with the CNRS have been cut loose after becoming in effect divisions of their industrial partners.

Vergnon is also concerned that the CNRS's collection of patents, rather than being a source of income, has cost almost FF125 million to maintain over the past decade. Among them are the controversial patent on the AIDS blood test, held jointly with the United States; legal expenses of FF43 million nearly offset revenues of FF50-FF60 million from royalties.

Part of the problem stems from an old policy of patenting inventions without regard to their commercial potential. The CNRS abandoned that approach in 1986 and has pruned its collection mercilessly, as well as abandoning the national agency responsible for transferring technology in favour of a new organization (see Nature 356, 275; 1992).

Industry has made money on the CNRS patents it has acquired; almost three-quarters of the FF1 billion generated by industrial collaborations results from product sales from patents taken out by the CNRS, with the rest from research contracts. The CNRS hands over its most potentially lucrative patents to companies in return for royalties of 3-5 per cent. CNRS officials say that their small share recognizes the considerable environmental investment that companies must make to commercialize an invention, but Finkbeiner and others believe that the arrangement is too generous to companies.

Ten years after the CNRS embraced industrial collaboration, it has dispelled the notion of fundamental research organizations as ivory towers with little impact on the economy. However, with the level of collaboration growing steadily, its researchers face the challenge of contributing more to the French economy without compromising their commitment to science.

Declan Butler 